\title{
Quality Seed Production in Medicinal and Aromatic Crops
}

\author{
M. Padma* \\ Medicinal and Aromatic Plants Research Station, Sri Konda Laxman Telangana State \\ Horticultural University, Rajendranagar, Hyderabad - 30, India \\ *Corresponding author
}

\section{A B S T R A C T}

\section{Keywords}

Senna,

Aswagandha,

Kalmegh, Velvet

bean

Article Info

Accepted:

07 June 2019

Available Online:

10 July 2019
All kind of crops can be produced in India with low cost labour availability and environment suitability for quality, vigorous and bold seed production, for domestic and export market which will not only save foreign exchange instead earn it besides empowering rural poor with skill, generate employment and income. High quality seed production and export is the best choice. In future, the seed sector is expected to be active and dynamic with hybrid varieties developed indigenously for domestic markets and commercial farmer. Vegetable seed and diversified crops like Medicinal and Aromatic Crops will ever have huge scope to success and will play an important role in economy. Earlier people used to collect medicinal plants from the wild sources. After that people started cultivation of these plants. Presently there is a great demand for medicinal plants in the world market. Medicinal plant cultivation is going in a commercial way. Quality seed is needed to cultivate the medicinal plants in commercial way. Medicinal and Aromatic Plants Research Station, Rajendranagar, Hyderabad is working on quality seed production of different medicinal plants like Senna, Aswagandha, Kalmegh, Velvet bean, Basil, Palmarosa, Isabgol.

\section{Introduction}

Seed is a key component among all inputs for sustainable crop production. It is estimated that quality of seed accounts for $20-25 \%$ of productivity. Crops are grown especially for seeds in an organized fashion to maintain quality in terms of genetic and physical purity. National Seeds Corporation (NSC) established in 1963. It is setup by aiming at promoting healthy development of seed industry in India establishing an adequate system of quality control, inspection for scientific processing, storage and marketing of seeds. At present the total Indian traded seed market is Rs. 20,000 crore. The global seed sector outlook by 2025 for major crops such as Brassica (Cabbage, cauliflower, broccoli), cucurbits (Muskmelon, watermelon, cucumber, squash), corn (Baby corn, sweet corn), Legumes (Pea, beans), leafy vegetable (Lettuce, spinach), Root - 
Bulb (Carrot, radish, onion), and Solanaceae (Pepper, eggplant, tomato) is a dynamic capture of semi-annual long range (10-15 year) forecasting data for global vegetable seed market. The Indian seed industry is the fifth largest seed market in the world, accounting for $4.4 \%$ global seed market after the US (27\%), China (20\%), France (8\%) and Brazil $(6 \%)$. In terms of global trade, India is self-sufficient in seed of vegetable, flower, fruit and field crops. It is expected that market size of Indian seed will grow at a rate of $11 \%$ per annum. With low cost labour availability and environment suitability for quality, vigorous and bold seed production, all kind of crops can be produced in India for domestic and export market which will not only save foreign exchange instead earn it besides empowering rural poor with skill, generate employments and income. High quality seed production and export is the best choice. In future, the seed sector is expected to be active and dynamic with hybrid varieties and open pollinated varieties developed indigenously for domestic markets and commercial farmer. Vegetable seed and diversified crops like Medicinal and Aromatic Crops will ever have huge scope to success and will play an important role in economy. Policy making and implementations shall be free Strength of public sector in $R \& D$ is needed to provide good quality seeds to the farmers. Focus on quality seed production besides development of package of practices for Medicinal and Aromatic Crops is on priority and need of the hour.

Medicinal plants may be defined as those plants that are commonly used in treating and preventing specific ailments and diseases and that are generally considered to be harmless to humans. Plant is an important source of medicine and plays a key role in world health. Traditional systems of medicine continue to be widely practiced on many accounts. Population rise, inadequate supply of drugs, prohibitive cost of treatments, side effects of several synthetic drugs and development of resistance to currently used drugs for infectious diseases have led to increased emphasis on the use of plant materials as a source of medicines for a wide variety of human ailments. Earlier, people used to collect medicinal plants from the wild sources. After that people started cultivation of these plants. Presently great demand for medicinal plants in the world market. Medicinal plant cultivation is going in a commercial way. Quality seed is needed to cultivate the medicinal plants in commercial way. Medicinal and Aromatic Plants Research Station, Rajendranagar, Hyderabad is working on quality seed production of different medicinal plants like Senna, Aswagandha, Kalmegh, Velvet bean, Basil, Palmarosa, Isabgol with an objective of production of quality seed as seed quality plays an important role in the production of medicinal and aromatic crops and making the seed available commercially.

\section{Materials and Methods}

\section{Raising of seedling}

Sweet Basil and Sacred Basil seed sown in raised beds and usually transplanted whereas Ashwagandha, Senna, Kalmegh, Velvet bean, Isabgol and Palmarosa are direct seeded in the field. The use of transplant makes the most efficient use of land and provides the best means of establishing a uniform and complete stand of plants. Seeds are sown on raised beds. The seed beds were of fertile and well drained. The bed area was incorporated with manures and fertilizers. Seed beds of $15 \mathrm{~cm}$ high and $0.8 \mathrm{~m}$ wide and convenient length are prepared. Seeds were sown in the seedbeds in rows of $6.0 \mathrm{~cm}$ apart and $0.5 \mathrm{~cm}$ deep. Thin layer of compost was applied on the bed before mulching with rice straw. The seedlings were thinned at the first true leaf 
stage. The seedling was ready for transplant in about 5 to 6 weeks. The experiment was conducted during 2016-17 and 2017-18 seasons at Medical and Aromatic Plant Research Station, Rajendranagar - 30

\section{Land preparation}

Land preparation was done to create a favourable condition for seedling establishment and subsequent crop management. If properly done, it eliminates most of the weeds and soil-borne pathogenic microorganisms. It also improves the water holding capacity, drainage, and aeration of the soil. Likewise, it facilitates field operations, such as furrow irrigation and weed control. Choose land with fertile, good drainage, and accessible to irrigation water. If soil is dry, irrigate it 3-4 days before land preparation. Temporary furrows can facilitate irrigation. Then the soil is rototilled or ploughed. If it is ploughed, the soil should be harrowed to achieve a fine tilth prior to bed formation. Apply compost and basal fertilizers and incorporate them into soil by rototilling (George, 1985).

\section{Transplanting}

A cloudy, cool weather condition and moist but not wet soil are ideal for transplanting. During sunny days, transplanting is best done in the late afternoon to allow the seedlings to recover at night. However, seedlings that are adequately hardened with slightly damaged roots could recover well when transplanted in a well-irrigated field, even on a hot day 6-9 days before transplanting, seedlings are hardened by slightly with holding water and exposing them to sunlight. The seedlings are thoroughly watered 12-14 hours before transplanting to the field. The ideal seedlings with 3-4 true leaves, stocky and disease-free. Generally, seedlings are ready to set in the field 4-6 weeks after sowing. The seedlings are transplanted by hand into a hole deep enough to bury a plant by following the spacing of $50 \times 30 \mathrm{~cm}$. After transplanting, press the soil firmly around the root, and irrigate furrows immediately. The crops like Ashwgandha, Senna, Kalmegh, Velvet bean, Isabgol and Palmarosa are sown directly after land is prepared thoroughly. The seeds are sown in lines or rows maintaining the distance between the plants as given below.

Ashwagandha: 30 x $10 \mathrm{~cm}$

Senna: 45 x $30 \mathrm{~cm}$

Kalmegh: $30 \times 15 \mathrm{~cm}$

Velvet Bean: 60 x $60 \mathrm{~cm}$

Isabgol: $30 \times 5 \mathrm{~cm}$

Palmarosa: 60 × $30 \mathrm{~cm}$

Basil transplanted: 50 x $30 \mathrm{~cm}$

The quantity of seed required per acre is given as

Ashwagandha - 5-6 Kgs

Senna - $5 \mathrm{Kg}$

Kalmegh - $200 \mathrm{~g}$

Velvet Bean -20 Kgs

Isabgol $-1.6 \mathrm{Kg}$

Palmarosa - 3-4 Kg

Sweet basil - $100 \mathrm{~g}$

Sacred basil - $100 \mathrm{~g}$

\section{Fertilization}

Adequate application of manures and fertilizers is very important for successful crop production. In the nutrition of seed crops, nitrogen, phosphorus, potassium, and several other elements play an important role for proper development of plants and seed. It is, therefore, advisable to know and identify the nutritional requirements of seed crops and apply adequate fertilizers.

The following fertilization rates are generally recommended for growing Medicinal and Aromatic Crops as given below. An adequate 
amount of compost (4t of Farm Yard Manure per acre) is essential to improve the efficiency of chemical fertilizers and to retain optimum soil physical/chemical conditions.

Ashwagandha: $20 \mathrm{Kg} \mathrm{N}: 20 \mathrm{~kg}$ P: $10 \mathrm{Kg} \mathrm{K}$

Senna: $20 \mathrm{Kg} \mathrm{N}: 20 \mathrm{~kg}$ P: $20 \mathrm{Kg} \mathrm{K}$

Kalmegh: $20 \mathrm{Kg} \mathrm{N}: 20 \mathrm{~kg}$ P: $20 \mathrm{Kg} \mathrm{K}$

Velvet Bean: $32 \mathrm{Kg} \mathrm{N}$ : $16 \mathrm{~kg}$ P: $32 \mathrm{Kg} \mathrm{K}$

Isabgol: $12 \mathrm{Kg} \mathrm{N}$ : $15 \mathrm{~kg}$ P: $10 \mathrm{Kg} \mathrm{K}$

Palmarosa: $20 \mathrm{Kg} \mathrm{N}: 20 \mathrm{~kg}$ P: $20 \mathrm{Kg} \mathrm{K}$

Sweet basil: $50 \mathrm{Kg} \mathrm{N}: 25 \mathrm{~kg}$ P: $25 \mathrm{Kg} \mathrm{K}$

Sacred basil: $50 \mathrm{Kg} \mathrm{N}: 25 \mathrm{~kg}$ P: $25 \mathrm{Kg} \mathrm{K}$

\section{Irrigation}

Irrigation is essential, the frequency and amount of water application are determined by the weather, soil conditions, the development stage, and depth of the root zone specific for the crop and variety.

The water holding capacity of the soil is a major factor that determines the frequency of irrigation.

A sandy soil must, therefore be watered more frequently than a clay soil. All Medicinal and Aromatic crops (annuals) are medium-rooted crops with a root-zone depth of about 10-40 $\mathrm{cm}$ in well-drained soil. Irrigate soil of at least $30 \mathrm{~cm}$ deep at a interval of 8-10 days during the drier periods. The method of irrigation depends on soil texture and furrow (surface) irrigation is used.

\section{Weed control}

Weed infestation also increases insect pests and diseases. The weeds should be controlled when the maximum weeds are tolerable but without affecting the crop yield. Weeds are controlled by physical/mechanical methods. Hand weeding was done twice by use of tools (hoe) to control the weeds in turn the attack of pests and diseases.

\section{Insect pests}

Insect infestation is one of the most limiting factors for accelerating yield potential of all crops. Medicinal and Aromatic Crops are less prone to pests and diseases except few such as damping off, leaf spot, leaf blotch and powdery mildew.

\section{Harvest and postharvest}

The time required from flowering to market varies with the crop. When the color dulls and inflorescence become brown in colour and the seeds become dark coloured are considered to be the indices for harvest. At market maturity, the seeds shed when the spikes pressed lightly. The harvesting was done in dry atmosphere by cutting the plants $10-15 \mathrm{~cm}$ above the ground late in the morning. The produce is threshed and seeds are separated. The produce is threshed preferably in the early morning for easy separation of seed from spikes, fruits and pods.

\section{Results and Discussion}

The experimental results of the investigation are presented under the following headings.

\section{Isolation of seed crops}

The seed crops were isolated from other nearby fields of the same crops and other contaminating crops as per requirement of the certification standards. Contamination was avoided through different methods.

\section{Space isolation}

By providing minimum specified distance as listed below from the sources of genetic contamination so that foreign pollens are unable to reach in viable state.

Ashwagandha: 200m

Senna: $50 \mathrm{~m}$ 
Kalmegh: $100 \mathrm{~m}$

Velvet Bean: 50m

Isabgol: $200 \mathrm{~m}$

Palmarosa: $200 \mathrm{~m}$

Sweet basil: $200 \mathrm{~m}$

Sacred basil: $200 \mathrm{~m}$

\section{Time isolation}

By adjusting the time of sowing i.e. keeping a gap of 15-20 days between sowing of varieties and cross-compatible crops was followed.

\section{Barrier isolation}

Isolation was achieved by physical barriers such as barrier crop grown of 5-6 ft height such as a Ambrette, an aromatic crop was grown around Palmarosa. Polythene sheet of optimum height of $4 \mathrm{ft}$ around the seed plot was erected around basil crops, Ashwagandha and Senna which reduce the movement of pollen.

\section{Discarding border rows}

Foreign pollens mainly pollinate the plants present on the outer periphery of the seed plot. Therefore, contamination can be reduced by discarding the produce of 5-6 lines on the outer periphery to maintain the purity.

\section{Selection of variety}

The variety for seed production must be a higher yielder, should possess disease resistance, earliness, grain quality, and adapted to the agro-climatic conditions of the region and shall be in line for commercial cultivation and acceptance.

\section{Quality seed}

A quality is one which is genetically pure, physically pure, physiologically active and is healthy as per prescribed seed certification standards.

To produce quality seed, important operations like rouging, weed control, Pest and diseases and harvesting of seed at right stage were followed.

To facilitate rouging operations and inspection of seed crops, slightly lower seed rates than usual recommendations was followed. Rouging operation done at Vegetative, flowering, Seed set stages.

\section{Rouging}

Adequate and timely rouging is extremely important in seed production. Rouging in crops Senna, Aswagandha, Kalmegh, Velvet bean, Basil, Henna, Palmarosa, Isabgol done at vegetative/ pre-flowering stage, flowering stage and maturity stages. Rouging was done in the morning or evening. Dull, excessively bright and windy days should be avoided for doing rouging operations. The back of the person doing rouging should be towards the sun was followed as mentioned (Annonymous, 2017).

\section{Weed control}

Effective weed control was done which is the basic requirement in producing good quality seed. Weeds may cause contamination of the seed crop besides reduction in yield due competition between crop and weed plants for light, space, moisture and nutrients. Portulaca, Parthenium, Cyperus are the main weeds found in fields of Medicinal and Aromatic Crops.

\section{Disease and insect control}

Effective control strategies were followed against diseases, insect pests and nematodes affecting production of quality seed. 
Medicinal and Aromatic Crops are less prone to pests and diseases except few such as damping off, leaf spot, leaf blotch and powdery mildew which were controlled by management.

\section{The medicinal and aromatic crops harvest}

Medicinal and Aromatic Crops were harvested when the seeds reach to market maturity after showing the harvest indices depending on the crop as reported by Rajeshwara Rao et al., (2012) in Ashwagandha, Meena et al., (2015) in Isobgol and Jitendra Kumar (2014) in Ocimum crops.

\section{Seed yield}

\section{Seed extraction}

Harvesting is done when fruits or pods or spikes are fully ripe. The pods or spikes or fruits are picked and collected and shade dried first. Seeds will be separated when spikes or pods are pressed on hard surface.

The operation is done late morning hours. The whole lot is cleaned, threshed and seeds are separated. Care was taken to avoid mixing of the varieties and crops. If any immature seeds, separated and Quality matured seed was dried in partial shade to a moisture content of $8 \%$ or below before storing.

The quantity of seed produced per acre is given as below

$$
\begin{aligned}
& \text { Ashwagandha }-30 \mathrm{Kgs} \\
& \text { Senna }-20 \mathrm{Kg} \\
& \text { Kalmegh }-5 \mathrm{Kg} \\
& \text { Velvet Bean }-30 \mathrm{Kgs} \\
& \text { Isabgol }-240 \mathrm{Kg} \\
& \text { Palmarosa }-30 \mathrm{Kg} \\
& \text { Sweet basil }-25 \mathrm{Kg} \\
& \text { Sacred basil }-10 \mathrm{Kg}
\end{aligned}
$$

\section{Processing and cleaning}

After receiving the unprocessed seed at processing shed, seed will be processed and cleaned. Sample will be drawn for testing the genetic purity, germination, physical purity. All remnant seed shall be incinerated. The cleaned seed checked for Seed cleaning, upgrading, seed treatment without mixing and damaging seed lots (Padmavati et al., 2012). Improvement in physical quality of seed lot by removal of undesirable material and upgrading of seed quality through removal of damaged and undersized seed with highest efficiency is defined as seed processing which involves drying, pre-conditioning, basic cleaning and grading as major steps.

\section{Drying of seed}

It is the most important factor in influencing the longevity and germination percentage of seed. Two common methods are sun drying and forced air drying. In Medicinal and Aromatic Plants Research Station, Rajendranagar followed simple sundrying. Seed is spread as thin layer on a tarpaulin until seed moisture level obtained to 8.0$10.0 \%$

\section{Seed cleaning}

Pre conditioning or pre cleaning operations carried as mentioned in Advances in Quality Seed Production of Vegetable Crops, CAFT 2017-18,308.

Basic seed cleaning operations done for separation of admixtures, dust and sand for upgrading the quality of cleaned seed.

\section{Seed treatment}

Seed treatment refers to exposing the seeds to certain agents, physical or chemical or biological, which are able to protect them 
from pests and provide good health to the seed and emerging plant.

Ashwagandha, Senna, Kalmegh, Velvet Bean, Isabgol, Palmarosa, Sweet basil and Sacred basil were treated with Dithane M-45 3g/kg seed and kept for storage.

\section{Seed Packaging or labeling}

Seed packaging or bagging is essentially the last operation before storage or marketing. After processing and treatment, seeds are packaged into containers of specified net weight (Vanangmudi, 2014).

The packaging consists of the following operations:

Filling of seed bags/ containers to an exact weight.

Placing leaflets in the seed bags/ containers regarding improved cultivation practices

Attaching labels, certification tags on the seed bags / containers, and closing them.

Storage of seed bags / containers.

\section{Types of packaging material}

\section{Moisture vapour permeable container}

Jute bag, cloth bag, paper bag, multiwall paper bag, non-wooven bags may be used. In Medicinal and Aromatic Plants Research Station, Rajendranagar cloth bags are used for packing of seed material meant for sale in the counter.

\section{Moisture vapour resistant container}

E.g., jute bag laminated with thin polythene film, polythene bags (200-300 gauge) may also be used.

\section{Moisture vapour proof container}

E.g. tin can, polythene bags (>700 gauge), aluminimum foil pouches, glass bottles. In Medicinal and Aromatic Plants Research Station, Rajendranagar seed lots are packed in aluminimum containers.

\section{Labeling}

All seed bags/ containers provided the information about

Crop

Variety

Class of seed

Address of the producer

Bags are labeled with tags according to the class of seed.

Seed tag should contain information about

Physical purity (\%)

Genetic purity (\%)

Moisture (\%)

Germination (\%)

Date of test

\section{Seed storage}

Seed storage is the "preservation of seed with minimum loss in viability and vigour until needed for sowing".

All kind of crops can be produced in India with low cost labour availability and environment suitability for quality, vigorous and bold seed production, for domestic and export market which will not only save foreign exchange instead earn it besides empowering rural poor with skill, generate employment and income.

High quality seed production and export is the best choice. In future, the seed sector is expected to be active and dynamic with hybrid varieties developed indigenously for domestic markets and commercial farmer. 
Vegetable seed and diversified crops like Medicinal and Aromatic Crops will ever have huge scope to success and will play an important role in economy.

The People earlier used to collect medicinal plants from the wild sources. After repeated enlightening the farmers are coming forward for cultivation of these plants.

Presently great demand for medicinal plants in the world market.

Medicinal plants are cultivated in a commercial way. Quality seed is needed to cultivate the medicinal plants. Medicinal and Aromatic Plants Research Station, Rajendranagar, Hyderabad is working on quality seed production of different medicinal plants and production technology, techniques to be followed for quality seed production in crops like Senna, Aswagandha, Kalmegh, Velvet bean, Basil, Palmarosa, Isabgol is recommended.

Improvement in physical quality of seed lot by removal of undesirable material and upgrading of seed quality through removal of damaged and undersized seed with highest efficiency in seed processing which involves drying, pre-conditioning, basic cleaning and grading are the major steps in production of seed in Medicinal and Aromatic Crops.

\section{References}

Anonymous (2017), Advances in Quality Seed Production of Vegetable Crops. CAFT 2017-18 PG 310.

George, R.A.T. 1985. Vegetable Seed Production Longman, New York Pp. 223-229.

Jitendra, K. 2014. Cultivation of Ocimum Technical Report. Directorate of Medicinal and Aromatic Plants Research ICAR.

Meena, V.D., Dotania, M.L., Meena, B.P, Das, H. and Beena. 2015. Isabgol (Plantago ovata Forsk.) - Medicinal Herb: Good source of Income Generation in water scarcity Regions, Popular Kheti. 3(4): 2-5.

Padmavati, S., Prakash, M., Ezhe,1 S. and Kamraj, S. 2012. A text book of Seed Science and Technology. New India Publication Agency (NIPA), New Delhi. Pp. 254-262.

Rajeswara, R., E.R. Rakut, Nagaraju, G. and Adinarayanam, G. 2012. Opportunities and challenges in the cultivation of Ashwagandha (Withania somnifera (L.) Dunal). Journal of Pharmacognosy. 3(2): 88-91.

Vanangamudi, K. 2014. Seed Science and Technology. New India Publication Agency (NIPA), New Delhi. Pp. 357366.

\section{How to cite this article:}

Padma, M. 2019. Quality Seed Production in Medicinal and Aromatic Crops. Int.J.Curr.Microbiol.App.Sci. 8(07): 604-611. doi: https://doi.org/10.20546/ijcmas.2019.807.075 